
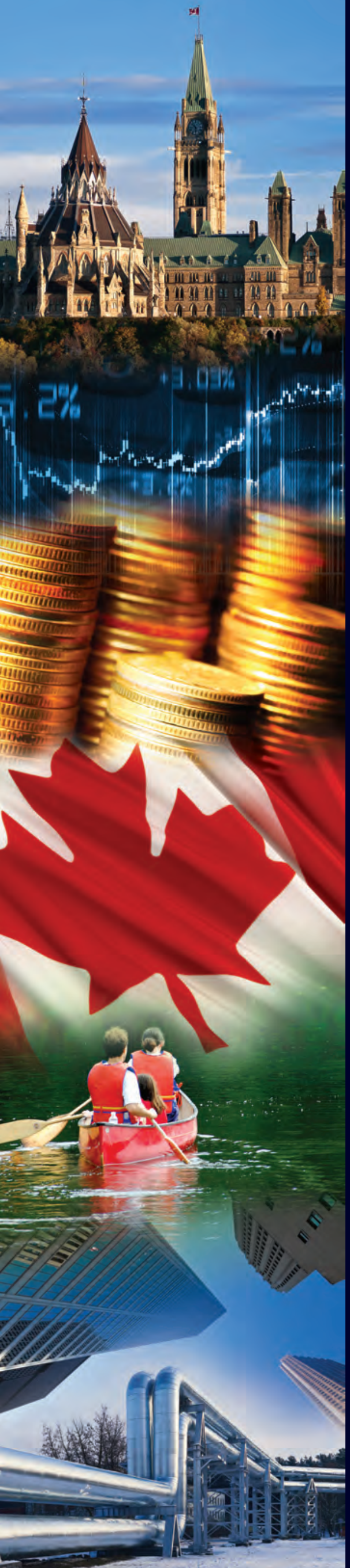

COMMENTARY

NO. 523

\title{
Cannabis Countdown: Estimating the Size of Illegal Markets and Lost Tax Revenue Post-Legalization
}

As Canada ends the prohibition of recreational marijuana, our projections indicate a continuing black market and shortages of legal marijuana supply that will result in forgone tax revenues in the first year of legalization.

Anindya Sen and Rosalie Wyonch 


\section{THE C.D. HOWE INSTITUTE'S COMMITMENT TO QUALITY, INDEPENDENCE AND NONPARTISANSHIP}

\section{ABOUT THE AUTHORS}

Anindya Sen is Professor of Economics and Director, Master of Public Service Program, Department of Economics, University of Waterloo.

Rosalie Wyonch is a Policy Analyst at the C.D. Howe Institute.

Commentary No. 523

October 2018

Industry Regulation and Competition Policy

$\$ 12.00$

ISBN 978-1-987983-79-1

ISSN 0824-8001 (print);

ISSN 1703-0765 (online)
The C.D. Howe Institute's reputation for quality, integrity and nonpartisanship is its chief asset.

Its books, Commentaries and E-Briefs undergo a rigorous two-stage review by internal staff, and by outside academics and independent experts. The Institute publishes only studies that meet its standards for analytical soundness, factual accuracy and policy relevance. It subjects its review and publication process to an annual audit by external experts.

As a registered Canadian charity, the C.D. Howe Institute accepts donations to further its mission from individuals, private and public organizations, and charitable foundations. It accepts no donation that stipulates a predetermined result or otherwise inhibits the independence of its staff and authors. The Institute requires that its authors publicly disclose any actual or potential conflicts of interest of which they are aware. Institute staff members are subject to a strict conflict of interest policy.

C.D. Howe Institute staff and authors provide policy research and commentary on a non-exclusive basis. No Institute publication or statement will endorse any political party, elected official or candidate for elected office. The views expressed are those of the author(s). The Institute does not take corporate positions on policy matters.
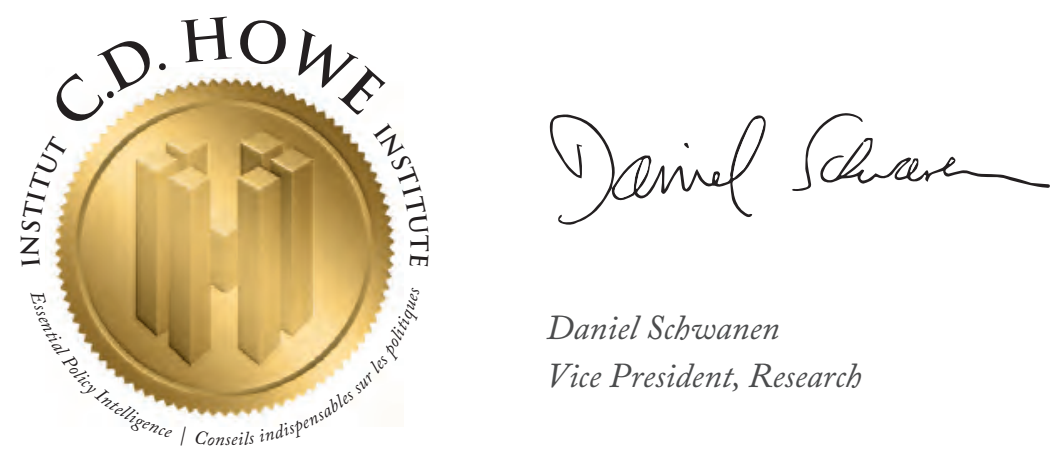

Daniel Schwanen

Vice President, Research 


\section{THE STUDY IN BRIEF}

With Canada ending the legal prohibition of recreational marijuana as of October 17,2018, governments across the country have been mobilizing to tackle the many policy challenges. But there has been a lack of policy discussion on whether supply from existing authorized producers will be sufficient to meet expected demand.

This Commentary contributes to the literature by estimating the size of the marijuana black market during the first year of legalization, October 2018 - September 2019. These estimates take into account legal-illegal price differences as well as the gap between market demand and available legal supply. Our results show that both pricing and supply shortages will contribute to maintaining the black market, resulting in lost tax revenues and a continued need to spend significant resources on law enforcement activities related to the market. Our projections indicate the size of the black market, including legal supply shortages, will be about 380 tonnes, or at least $\$ 2.5$ billion during the first year of legalization.

This further suggests that forgone government revenues based on the coordinated excise tax framework and GST/HST/QST could be about $\$ 800$ million. This loss can be attributed to a shifting mix of black market activity and legal market supply shortages, depending on the legal price and availability of supply. Using midpoint estimates for demand, our supply projections indicate that at $\$ 9$ per gram, 87 percent of the resulting tax loss would be attributed to the black market and the remaining 13 percent to supply shortage in the legal market.

There are various options that Canadian governments could employ to reduce this potential loss. Provinces should ensure regulations facilitate a competitive and convenient legal retail market. The federal government should focus on ensuring that it does not impede production more than is necessary to protect public health so there will be enough legal marijuana to supply these retail outlets. In addition, the federal government and Health Canada should develop regulations for edible and concentrated marijuana products. These products are already available on the black market, providing it a significant competitive advantage since they will not be part of the legal regime, at least at first. While our results predict initial shortages in legal supply, the market should be able to adjust as time goes on.

C.D. Howe Institute Commentary $($ is a periodic analysis of, and commentary on, current public policy issues. Michael Benedict and James Fleming edited the manuscript; Yang Zhao prepared it for publication. As with all Institute publications, the views expressed here are those of the authors and do not necessarily reflect the opinions of the Institute's members or Board of Directors. Quotation with appropriate credit is permissible.

To order this publication please contact: the C.D. Howe Institute, 67 Yonge St., Suite 300, Toronto, Ontario M5E 1J8. The full text of this publication is also available on the Institute's website at www.cdhowe.org. 


\section{On Oct. 17, 2018, Canada will become the second country, after Uruguay, to legalize the production and retail distribution of recreational marijuana.}

There are many concerns about the effects of legal access, such as the long-run health impact on youth, whether marijuana acts as a possible gateway drug to illegal substances, whether it results in an increase in impaired driving and so forth. This Commentary addresses a different concern: the likely size of the black market after legalization. From a policy perspective, this is crucial, as the federal government has made it clear that a key objective of legalization is the elimination of black markets and their associated criminal activities (LeBlanc and Hagar, 2017).

In this respect, federal and provincial governments have agreed to keep marijuana taxes low, with an excise tax that is the higher of either $\$ 1$ per gram or 10 percent of the producer's selling price (Department of Finance 2017a). The federal, provincial and territorial governments have further agreed to a coordinated excise taxation framework where the federal government will keep 25 percent of tax revenues up to $\$ 100$ million with the remainder going to the provinces (Department of
Finance 2017b). ${ }^{1}$ As well, Ottawa has articulated a target price of around $\$ 10$ per gram.

However, large black markets are likely to remain, even with quite modest tax regimes. ${ }^{2}$ Regardless of any significant legal-illegal price differential, a black market will clearly thrive if legal domestic supply is not able to meet demand. ${ }^{3}$ This is particularly relevant given the current ease in ordering illegal marijuana online and the ability of firms to deliver products to consumers through innocent parties such as Canada Post (Perkel 2017). Indeed, the website www.weedmaps.com allows consumers to locate distributors by geographic location.

This Commentary contributes to the literature by estimating the size of the marijuana black market during the first year of legalization, October 2018 - September 2019. These estimates are constructed taking into account legal-illegal price differences as well as the gap between market demand and available legal supply. Our research makes another important contribution by attempting to capture total demand and supply by not only using data

We acknowledge extremely helpful comments from Mike Veal, Ergete Ferede, Åke Blomqvist, Phil Curry, Stephen Easton, Ian Irvine, Owen Adams and seminar participants at the 2018 Deloitte-University of Waterloo Tax Symposium, Canadian Economics Association Conference. The authors retain responsibility for any errors and the views expressed.

1 Manitoba is the only province that did not agree to the coordinated excise tax framework. It is assumed throughout that Manitoba has an excise tax for cannabis that is similar to the coordinated framework: a federal rate of 25 cents per gram or 2.5 percent, whichever is higher, and an additional 75 cents or 7.5 percent, whichever is higher, in provincial excise tax.

2 Sen and Wyonch (2017) demonstrate how even small increases in taxation can lead to large illegal markets.

3 Consumers will have the ability to grow their own marijuana as an alternative to either legal or illegal retail. It is unclear how many people will choose this option, and though it is legal, this consumption would not be taxed. For the purposes of this analysis, we assume that the amount of home-grown marijuana is negligible to the total volume of the market. We justify this assumption with the observation that Canadians are allowed to make their own wine and beer and grow tobacco for personal use, and those activities are minor in terms of the total alcohol and tobacco markets. 
on dried flowers but also by including edibles and edible oils and converting them into dried marijuana equivalents based on dosage. We use these estimates to calculate potential losses in government tax revenue corresponding to both supply shortages and illegal activity.

Our results indicate that at current production levels, legal supply will meet only roughly 30 percent to 60 percent of total demand. ${ }^{4}$ This large interval arises because of the difficulty associated with predicting actual market demand. Still, the important policy conclusion is that there will not be enough legal supply, especially during the first half of the year following legalization, primarily because of the slow rate of licensing producers. Shortages in legal supply will likely be short lived due to the increase in licensed producers and the expansion of production capacities over time. There is also a possibility of legal supply meeting legal demand simply because many consumers choose the black market as their source of supply.

When considering the black market and supply shortages, the total lost marijuana tax revenues from the proposed federal excise, goods and services taxes, and provincial sales taxes is about $\$ 800$ million in the first year. These are significant losses, and the federal government should take immediate steps to ensure that regulatory barriers do not unnecessarily hinder licensed producers from producing adequate supply to meet national demand.

The loss in tax revenue is especially large considering our projections indicate that federal and provincial revenues from excise and sales taxes on marijuana will only be about $\$ 300-\$ 600$ million in the first year of legalization. Indeed, if the entire marijuana market were supplied legally and taxed, the potential revenue from both excise and goods and services taxes would be about $\$ 1.3$ billion. In addition, to improving the competitiveness of the legal market with the existing black market, Health Canada should develop regulations for the sale of edible and concentrated marijuana products. To further minimize black market activity, the provinces should ensure their policies are conducive to competitive retail distribution with similar prices to those in the black market. As well, both levels of government need to increase enforcement of marijuana laws at the outset of legalization.

\section{THERE AND BACK AGAIN: LEGAL MARIJUANA IN CANADA}

A brief history of marijuana in Canada, how prohibition came about and was subsequently loosened provides useful context for the current state of affairs in the regulated cannabis industry. Marijuana was made illegal in Canada in 1923 when the Minister of Health added it, without explanation, to The Opium and Narcotic Drug Act, 1911 during a review of the legislation. In 1938, Parliament enacted laws that prohibited the cultivation of cannabis without a permit obtained by Health Canada. ${ }^{5}$

Canada is also party to a number of UN conventions and associated measures to limit trade in illicit drugs enacted through the Controlled Drugs and Substances Act. The cumulative effect is that Canada and other parties must limit trade in such drugs to medical and scientific purposes, make their non-medical possession and trade a criminal offence, impose punishments for these offences and develop measures to reduce demand (Mackay and Phillips 2016).

Since its prohibition, non-medicinal cannabis use has been the subject of numerous government commissions and committee reports that have

4 Note that "legal supply" here refers to commercially produced legal supply and does not include home-grown marijuana.

5 While marijuana was illegal for recreational consumption, cultivation of hemp for textiles and scientific research was allowed prior to 1938 . 
concluded that prohibition is not sufficient to discourage use and that attempting to ban marijuana entails a host of negative consequences that outweigh the possible benefits. As a result, prohibition is infeasible policy in the long run. ${ }^{6}$

Despite being illegal for almost a century, Canada has a prolific and highly functional marijuana black market, as do many other countries. Between 2010 and 2015, 135 nations accounting for 92 percent of the world population reported varying degrees of direct or indirect illegal cannabis production to the UN Office of Drugs and Crime (UNODC 2017). ${ }^{7}$ Statistics Canada estimates that Canadians consumed about 775 tonnes of cannabis in 2017 (Statistics Canada 2018a). Furthermore, a BC study that analyzes illegal grow operations estimates that province had up to 17,500 "growops" in 2000 (Easton 2004).

One-in-three Canadian cannabis users report obtaining their supply from family or friends. Only 14 percent of survey respondents accessed cannabis through an online licensed producer and 9 percent grew the product themselves (Statistics Canada 2018b). ${ }^{8}$ After legalization, an illegal marijuana market will remain through informal networks of peers who have trust relationships and find illegal supply convenient and easy to access.

In addition, there are also the illegal dispensaries to consider. A quick scan of weedmaps.com reveals a significant number of brick and mortar stores in Toronto and Vancouver. As well, there are numerous cross-country and local delivery online services. Indeed, there were more than 100 such

\begin{tabular}{|c|c|c|}
\hline & Storefronts & \# of Products \\
\hline Montreal & 5 & $8-45$ \\
\hline Toronto & 32 & $2-60$ \\
\hline Calgary & 1 & 14 \\
\hline Vancouver & 23 & $8-316$ \\
\hline
\end{tabular}

delivery services advertised in each of Canada's four largest cities (Table 1).

Currently, a shopper can survey lists of available products and their qualities and prices, read reviews of open dispensaries and make a choice about where to purchase. These retail outlets offer more products than will be available in the legal market. Among them: high THC inhalable concentrates such as hashish or "shatter;" edible products from brownies to chocolate bars; topical moisturizers; bath bombs and so forth. In contrast, the legal market will initially supply only dried marijuana and cannabis oils intended for ingestion. The current availability of a range of products at differing prices and qualities from dispensaries and online retail suggests that a profitable illegal market will remain after legalization. The key point is that the availability of such edible, topical and concentrated marijuana products gives the illegal market an advantage over the legal market, which will not supply these products, at least at the outset.

6 See Le Dain, Lehmann and Stein (1972) and Senate Special Committee on Illegal Drugs (2002).

7 The actual amount of cannabis produced annually is difficult to assess, given that most indicators come from law enforcement bodies and reflect the amounts seized, not produced. Based on quantities of cannabis intercepted, UNODC reports that trafficking seems to have stabilized, with 6,000 tonnes of cannabis herb (dried cannabis leaves or flowers) and 1,300 tonnes of resin (processed byproduct of the plant that is generally of higher potency) intercepted annually (UNODC 2017).

8 There is some overlap in responses, as multiple responses were permitted. Nearly three-quarters (72 percent) of cannabis users reported obtaining cannabis from a single source. 
Production, consumption and access to marijuana in Canada are currently governed by the Access to Cannabis for Medical Purposes Regulations (ACMPR). These regulations came into effect on Aug. 24, 2016, replacing the Marihuana for Medical Purposes Regulations (MMPR) (Health Canada 2016a). ${ }^{9}$ Under the ACMPR, retail storefronts remain illegal, but the regulations allow for both a commercial industry and personal production for medical purposes. Applications for licensing to produce marijuana are submitted to Health Canada for a decision. Health Canada also inspects producers in order to ensure compliance with all regulations. It is also responsible for reviewing applications from individuals who want to produce a limited amount of cannabis for their own medical purposes or want permission to delegate production to another individual.

Physicians act as gatekeepers in terms of prescribing the amount of dried marijuana that individuals are allowed to legally consume. Individuals can access marijuana legally by placing orders directly with authorized producers, by growing their own plants or by designating another individual as a producer, with Health Canada's permission. Individuals granted a licence to grow marijuana plants have to be specific about whether they will be grown indoors or outdoors. If outdoors, they must confirm that the production facilities are not adjacent to a school, public playground, daycare or other public places largely frequented by children. Individuals are also responsible for safe storage and securing their marijuana products.

In the current regulatory environment, firms that want to supply recreational marijuana postlegalization must apply for a licence under the ACMPR as a producer of medical marijuana. When the legislation that allows for production, distribution, sale and possession of cannabis for non-medicinal purposes takes effect in October, ${ }^{10}$ a producer licensed under the current regime will automatically be licensed to continue those activities for medicinal and/or recreational cannabis under the Cannabis Act.

\section{THE COMMERCIAL CANNABIS INDUSTRY}

Since the creation of a commercial medical marijuana industry in 2013, there has been, unsurprisingly, a rather sharp increase in commercial activity. Production, sales, inventories and the number of licensed producers have all been increasing (Figure 1). Since the beginning of 2016, production has increased at a compound annual rate of 131 percent. Sales grew faster than inventories, 152 percent annually compared to inventories at 117 percent. ${ }^{11}$ The number of producers has also increased. Only 27 producers were licensed between 2013 and the beginning of 2016. By the end of 2017, this number had more than tripled to 84 . As of June 30, 2018, the number

9 In 2013, the Marihuana for Medical Purposes Regulations (MMPR) enabled the existence of a commercial industry that could legally produce and distribute marijuana for medical needs. These regulations also eliminated the ability of medical patients to grow their own marijuana or designate another person to produce it for them. In 2016, the Federal Court invalidated MMPR because: “... the regulatory restrictions in the MMPR upon the individuals ... does not bear a connection to the objective of the legislation and is therefore arbitrary. The access restrictions did not prove to reduce risk to health and safety or to improve access to marihuana - the purported objectives of the regulation.” (Allard, Beemish, Hebert, Davey 2016).

10 Bill C-45, An Act respecting cannabis and to amend the Controlled Drugs and Substances Act, the Criminal Code and other Acts (the Cannabis Act).

11 Since the inception of the legal commercial market, inventories have increased more than production, less sales, in most quarters. The source of this additional inventory is unclear. 


\section{Figure 1: Commercial Medical Marijuana Market}

Volume of Marijuana

(tonnes)

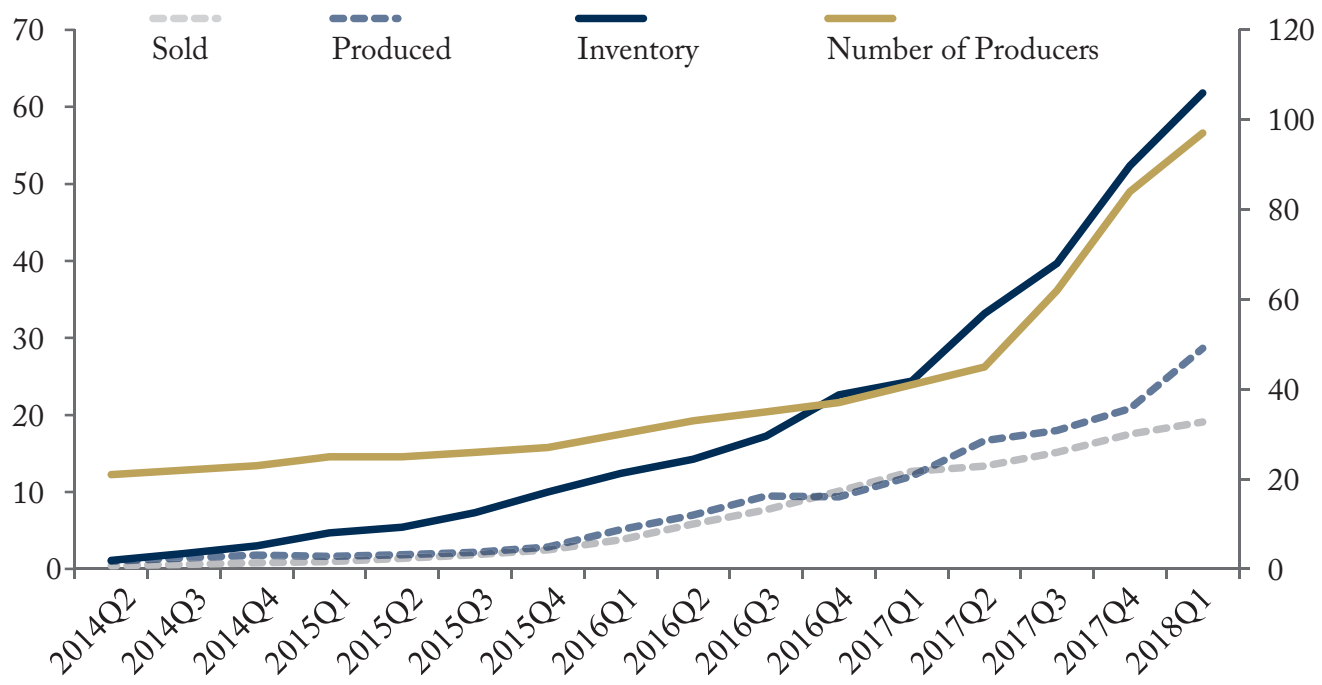

Note: Volume of marijuana is listed in tonnes of dried marijuana equivalent with quantities of cannabis oil converted using the pharmacokinetic equivalency factor calculated below (1.20606).

Source: Health Canada (2018).

of authorized medical cannabis producers stood at 112 .

This growth is a result of businesses and government preparing for the legalization of recreational marijuana consumption and possession. However, of all the producers licensed at the end of 2017, 40.5 percent had been licensed within the last six months of that year. This is important because producers must still obtain a sales licence after an inspection of their production facility. ${ }^{12}$ In addition, there is a three-to-nine-month required gestation period between receiving a production licence and the ability to harvest a crop..$^{13}$ Furthermore, the product likely requires additional processing before being delivered to market. Therefore, it is highly unlikely that firms authorized from January 2017 onwards will be able to supply marijuana to consumers when the recreational product becomes legal on October 17.

12 Health Canada has streamlined a number of processes related to obtaining the necessary security screenings and sales and production licences in order to reduce the time required to process applications. See Improving the Licensing of Production of Cannabis For Medical Purposes at https://www.canada.ca/en/health-canada/news/2017/05/improving_the_ licensingofproductionofcannabisformedicalpurposes.html.

13 Variable gestation times are required for crops grown from seedlings and seeds and depend on the licensed producer's ability to purchase or transfer immature plants from another licensed facility. 


\section{ESTIMATING DEMAND AND SUPPLY}

To determine the potential for market imbalances in the budding legal recreational market, we construct estimates of demand and supply. We then estimate the potential excise and tax revenue shortfalls that stem from production capacities or inventories being insufficient to supply the recreational market, as if there were no black market activity. Potential tax revenue losses due to supply shortfalls will likely be overstated, since the black market will not be immediately eliminated. We extend the analysis to consider the illicit market and prices and attribute potential tax losses to either black market activity or insufficient legal supply.

\section{DEMAND}

The first step is to construct measures of marijuana demand. We use estimates of actual and projected recreational marijuana consumption in other jurisdictions to make projections for the Canadian market. These estimates are benchmarked with market volume estimates from official government sources. ${ }^{14}$

The Parliamentary Budgetary Office (PBO) estimates 655 tonnes of marijuana will be consumed in Canada in 2018 (PBO 2016). Statistics Canada, using health, addiction, drug and alcohol usage surveys collected over 50 years, estimates domestic consumption of about 646 tonnes to 698 tonnes in 2015 (Macdonald and Rotermann 2017). We use these estimates as possible measures of postlegalization demand.

We construct additional measures by estimating recreational marijuana demand through mapping pre- and post-legalization estimates of market demand in Colorado and Washington, in per-capita terms, to the Canadian market. ${ }^{15}$ The Marijuana Policy Group, a Denver-based economic and policy consulting firm, estimated 2014 Colorado marijuana consumption of 121.4 tonnes (Light et al. 2014). However, this estimate is based only on the consumption of dried flowers. In order to express consumption in per-capita terms, we convert market-volume estimates into grams and then divide the number by the population that was at least 21 , the legal consumption age in 2014 (Table 2).

The 2015 annual update of the Marijuana Enforcement Division of the Colorado Department of Revenue reports that 109,578 pounds of medical and 38,660 pounds of recreational flowers were sold in 2014, the first year of legalization. In addition, some 4.8 million units of edible products were sold in the same year (Brohl, Kammerzell and Koski 2015). The challenge is to somehow convert the edibles into comparable dried flower equivalents. Most edible products sold in Colorado contain more than one 10 milligram serving. Colorado imposes no limit on the amount of Tetrabydrocannabinol (THC) - the main psychoactive compound in marijuana - medical edibles may contain, while recreational products are limited to 100 milligrams of THC per edible. Given the range of products available, we assume a standard concentration of 100 milligrams per edible. In addition, the method of consumption matters: marijuana has different effects on the body, depending on whether it is inhaled or ingested. Calculations based upon different uptake routes and speeds for psychoactive compounds estimate that

14 Another approach to estimate marijuana demand would be through a structural model as done by Jacobi and Sovinsky (2016) using Australian data. However, we are unaware of comparable Canadian data that would enable us to construct a similar model.

15 The pre-legalization demand estimate for marijuana in Colorado is included for completeness. Basing demand estimates on only post-legalization outcomes risks dramatically underestimating real underlying demand as only the legal market is measured. Pre-legalization estimates include black market considerations. 
one milligram of THC in edible form is equivalent to 5.71 milligrams in smokable form (Orens et al. 2015). ${ }^{16}$

Meanwhile, Washington state allows for the sale of cannabis oils and extracts that will not be available in the legal market in Canada at the outset of legalization. To incorporate them into estimates of total demand, these more concentrated products are converted to their equivalent in dried marijuana by relative average THC content. Since both concentrated extracts and dried marijuana are inhaled, the pharmacokinetic effects are similar, and the amount of psychoactive substance is the appropriate comparator (Orens et al. 2015).

Canadian market demand estimates are calculated by multiplying per-capita consumption estimates by the number of persons of legal age to purchase cannabis (aged 18 and over, or 19 and over, depending on province $)^{17}$ in Canada $(29,405,587)$ in 2017. Table 2 displays these estimates as well as demand estimates for Washington and Colorado.

Taken together, these estimates form an interval within which national demand should fall during the first year of legalization. The average of Canadian demand estimates, including and excluding extracts and edibles, show about 600 tonnes of marijuana as the total market demand for marijuana. Given the similarity of the estimates and the uncertainty surrounding Canadian demand for edibles and extracts, we use the 95-percentconfidence interval of demand associated with the average, excluding derivative marijuana products. A valid criticism might be that this interval (384 tonnes to 800 tonnes) is quite large. It is similar, however, to the range of demand estimated by the $\mathrm{PBO}$, which projects demand between 378 tonnes and 1,017 tonnes in 2018.
Similarly, Statistics Canada estimates household marijuana consumption of 773 tonnes in 2017 (Statistics Canada 2018a). In addition, a larger interval of demand estimates is prudent, given the variable nature of retail distribution that has emerged. Specifically, unlike in Colorado and Washington, Canadian consumers will not be restricted to brick and mortar retail outlets, as they will also be able to order online. This is relevant, as some consumers may initially be apprehensive about being seen at marijuana outlets. However, the ability to make online purchases and maintain relative anonymity might actually result in much larger demand in comparison to what occurred in the states that have legalized marijuana.

\section{Supply}

Constructing an estimate of legal national supply is challenging. Current sales numbers are limited to medical marijuana. However, current medicinal marijuana producers will also supply the recreational market, meaning current inventories are growing in anticipation of the recreational market. But historical market data reflect limited production and are not current enough to get an accurate picture of the recent growth in production capacities of existing and new marijuana producers.

Still, inventory, production, sales and other medical marijuana market data are available from Health Canada from the second quarter of 2014 to the first quarter of 2018. Using this publicly available data, we can analyze the relationship between the number of producers, production, sales and inventory in dried marijuana and cannabis oil. We use the average dosage equivalency (1.2 gram oil = 1 gram dried) to convert cannabis

16 For calculation details, see the Appendix.

17 For provinces and territories yet to set the minimum legal age to purchase recreational marijuana, we assume the federal minimum age of 18 . 


\section{Table 2: Canadian Marijuana Market Demand Estimates Extrapolated From Other Jurisdictions*}

\begin{tabular}{|c|c|c|c|c|c|}
\hline & Year & $\begin{array}{l}\text { Market Volume } \\
\text { (tonnes) }\end{array}$ & $\begin{array}{l}\text { Population } \\
\text { (legal age) }\end{array}$ & $\begin{array}{l}\text { Consumption } \\
\text { (g/capita) }\end{array}$ & $\begin{array}{l}\text { Canadian Market } \\
\text { Volume (tonnes) }\end{array}$ \\
\hline \multirow{3}{*}{ Colorado } & $\begin{array}{r}2014 \\
\text { (pre-legalization) }\end{array}$ & 121.4 & $3,858,197$ & 31.5 & 925.4 \\
\hline & 2014 & 83.3 & $3,858,197$ & 21.6 & 635.0 \\
\hline & $\begin{array}{r}2014 \\
\text { (excluding edibles) }\end{array}$ & 67.2 & $3,858,197$ & 17.4 & 512.5 \\
\hline \multirow{6}{*}{ Washington } & 2015 & 53.6 & $5,279,130$ & 10.2 & 298.6 \\
\hline & 2016 & 126.5 & $5,376,089$ & 23.5 & 692.1 \\
\hline & 2017 & 176.3 & $5,476,122$ & 32.2 & 946.8 \\
\hline & $\begin{array}{r}2015 \\
\text { (excluding extracts) }\end{array}$ & 35.4 & 5279130 & 6.7 & 197.0 \\
\hline & $\begin{array}{r}2016 \\
\text { (excluding extracts) }\end{array}$ & 86.4 & 5376089 & 16.1 & 472.4 \\
\hline & $\begin{array}{r}2017 \\
\text { (excluding extracts) }\end{array}$ & 113.3 & 5476122 & 20.7 & 608.3 \\
\hline PBO & 2018 & 655 & & 22.3 & 655 \\
\hline Statistics Canada & 2017 & 773.3 & 29405587 & 26.3 & 773.3 \\
\hline \multicolumn{5}{|l|}{ Average } & 610.6 \\
\hline \multicolumn{5}{|c|}{ Average - excluding derivative products } & 592.0 \\
\hline \multicolumn{6}{|c|}{$\begin{array}{l}\text { Notes: Data for Washington in } 2017 \text { were only available for the first } 4 \text { month of the year. These values were summed and multiplied to } \\
\text { estimate } 2017 \text { total demand. The } 95 \text { percent confidence interval for average demand estimates are [455.7,765.5] including edibles and } \\
\text { concentrates and [384.0,800.0] excluding edibles and concentrates. } \\
\text { *We have excluded other comparator jurisdictions such as Alaska and Uruguay because their estimates of pre- and post-legalization demand } \\
\text { yield both the highest and lowest value, calling into question their validity as market estimates. News reports suggest that Uruguay has a } \\
\text { shortage of supply, so using production and consumption estimates from that legal market would include a bias due to that factor. }\end{array}$} \\
\hline
\end{tabular}

oil inventories into an equivalent weight in dried cannabis. ${ }^{18}$

The resulting estimates of total marijuana inventories (including cannabis oil and dried marijuana) show that licensed producer inventories grew by 132 percent, from 22.6 tonnes at the end of 2016 to 52.4 tonnes at the end of 2017. In the same time frame, 67.5 tonnes of cannabis were produced, of which 58.7 tonnes were sold to medicinal consumers.

To estimate the marijuana supply available to the future recreational market, we first analyzed current marijuana market data to establish relationships among inventories in dried marijuana equivalent, 
the number of producers and the quantity that each produces. ${ }^{19}$ An increase in authorized producers should be associated with more supply and inventory.

The number of licensed producers is lagged by nine months (three quarters) in order to take into account the gestation period between obtaining approval and actually being able to sell marijuana products. To account for efficiency gains as producer capacities grow, the regression includes the amount produced per producer. To account for the medicinal market, the amount of medical marijuana sold per producer is also included. The resulting estimate shows that each additional licensed producer contributes 1,150 kilograms of inventory nine months after beginning production (Table A-1), which is statistically significant at the 1-percent level. ${ }^{20}$

To estimate the supply of marijuana that will be available for recreational consumption, we (a) assume that Health Canada will continue to license producers at the average rate of the last year (16.5 per quarter), (b) project production capacity increases based on the historical quadratic trend $\left(\mathrm{R}^{2}=0.92\right)$ and (c) also project medicinal sales based on their quadratic trend over time $\left(\mathrm{R}^{2}=99\right)$. We project a quadratic growth trend in production capacity because it takes time to build the facilities and receive all the necessary regulatory checks before producing for the recreational market. Also, prior to the federal government announcing its intention to legalize, legal marijuana production capacity was aimed at supplying the medicinal market. The market data covers a period of rapid expansion in capacity to supply the soon-to-be-legal recreational market. Given the potential for a supply shortage, rapid growth in production capacity can be expected as producers expand to meet this new demand.

The resulting estimate shows that marijuana available to supply the recreational market will total about 210 tonnes by the end of the first year of legalization (Table 3). The implication here is that sales to medicinal consumers will maintain previous growth and that any production and inventory in excess of these sales would be directed to the recreational market. Inventory should be thought of as accumulation of production in excess of medicinal consumption, not as held inventories.

\section{ESTIMATING TAX LOSS}

\section{Tax Losses Due To Supply Shortages}

Using the average of estimates for marijuana demand and the above supply estimate, we can examine the implications of the supply shortage for tax revenues. Assuming the existing inventories would be completely exhausted to serve the legal recreational market, we estimate potential tax loss for the first year of legalization based on a pre-tax price of $\$ 9$ per gram, consistent with the average price listed by ACMPR producers in 2017 (Martin 2018). Additionally, we assume the percapita demand is uniformly distributed among the population that is of legal age to consume.

The taxes applied are an excise tax of $\$ 1$ per gram and sales tax at the relevant federal/provincial rate. The legal supply of marijuana will likely meet only about 38 percent of total market demand in

19 Data on the volume of sales, production and inventory are sourced from Health Canada's quarterly ACMPR market data from April 2014 to March 2018. Market data from April 2017 to March 2018 is monthly. To remain consistent with previous quarters, this data is aggregated to quarterly. The number of producers is sourced from Health Canada's public listing of all active marijuana licences and their date of initial licensing.

20 For details and alternative model specifications that we consider, see Appendix. 


\section{Table 3: Projecting Available Marijuana Supply}

\begin{tabular}{|l|c|c|c|}
\hline & $\begin{array}{c}\text { Number of Licensed Producers } \\
\text { (nine-month lag) }\end{array}$ & $\begin{array}{c}\text { Average Production Capacity } \\
\text { (tonnes) }\end{array}$ & $\begin{array}{c}\text { Inventory of Marijuana } \\
\text { (tonnes) }\end{array}$ \\
\hline $2018 \mathrm{Q} 1$ & 45 & 0.64 & 61.72 \\
\hline $2018 \mathrm{Q} 2$ & 62 & 0.64 & 84.90 \\
\hline $2018 \mathrm{Q} 3$ & 84 & 0.73 & 122.08 \\
\hline $2018 \mathrm{Q} 4$ & 97 & 0.83 & 146.13 \\
\hline $2019 \mathrm{Q} 1$ & 111 & 0.93 & 171.89 \\
\hline $2019 \mathrm{Q} 2$ & 127.5 & 1.04 & 201.25 \\
\hline $2019 \mathrm{Q} 3$ & 144 & 1.15 & 231.03 \\
\hline
\end{tabular}

Source: Authors' calculations.

first year. ${ }^{21}$ The estimated shortage of legal supply is associated with about $\$ 380$ million in lost excise tax revenues and an additional $\$ 426$ million loss in provincial and federal sales taxes (Table 4). If the entire marijuana market were legally supplied and taxed, total revenues from excise and sales taxes would be about $\$ 1.3$ billion. With the projected supply shortage, however, tax revenues will only be about $\$ 490$ million.

\section{Tax Losses Due to Legal-Illegal Price Differentials}

The estimates of potential tax loss in the previous section are relative to the theoretical ideal, where all consumption immediately switches from the illicit market to the legal one. This does not take into account Canada's existing prolific black market for marijuana. The budding legal market will have to compete with the illicit market. To put the new market in a more realistic context, this section considers price in the black market in comparison to price and supply estimates for the legal market and estimates potential tax losses attributable to supply shortages, legal and illegal price differentials, and the associated black market activity.

Price and convenience are the two most important areas where the legal market will have to compete with the illicit market to get consumers to change their behaviour. Daily users of cannabis will make up the bulk of recreational demand and are also the most price sensitive (PBO 2016). Approximately 56 percent of cannabis users in Canada consume it in some form at least weekly (Statistics Canada 2018b). In addition, results from Washington state following a tax change showed that a 2.3 percent increase in the price of marijuana decreased demand by 0.95 percent (Hansen et al. 2017). Consumers did not decrease their marijuana consumption but instead appeared to substitute

21 This represents the midpoint estimate for demand. Over the 95-percent-confidence interval of demand for marijuana, legal supply will meet 30 percent to 60 percent of market demand. Using the lowest (197 tonnes) and highest (947 tonnes) estimates from the sample of marijuana markets suggests legal supply would meet 25 percent to 75 percent of total demand. 


\section{Table 4: Estimated Tax Loss due to Supply Shortage of Marijuana, 2018Q4 - 2019 Q3}

\begin{tabular}{|l|c|c|c|}
\hline & $\begin{array}{c}\text { Demand } \\
\text { (tonnes) }\end{array}$ & $\begin{array}{c}\text { Excise Tax Loss } \\
\text { (\$millions) }\end{array}$ & $\begin{array}{c}\text { Sales Tax Loss } \\
\text { (\$millions) }\end{array}$ \\
\hline Canada (total) & 610.6 & 379.5 & 425.7 \\
\hline British Columbia & 81.2 & 37.8 & 31.8 \\
\hline Alberta & 69.6 & 32.4 & 0.0 \\
\hline Saskatchewan & 18.6 & 8.7 & 9.3 \\
\hline Manitoba & 21.5 & 10.0 & 105.2 \\
\hline Ontario & 235.0 & 109.6 & 79.3 \\
\hline Quebec & 142.1 & 66.2 & 7.2 \\
\hline New Brunswick & 12.8 & 6.0 & 9.2 \\
\hline Nova Scotia & 16.4 & 7.7 & 1.4 \\
\hline Prince Edward Island & 2.5 & 1.2 & 5.0 \\
\hline Newfoundland and Labrador & 9.0 & 4.2 & 0.0 \\
\hline Territories & 1.8 & 0.9 & 181.8 \\
\hline Federal Government & & 101.0 & \\
\hline Source: Authors' calculations. & & & \\
\hline
\end{tabular}

cheaper, lower-quality products. To determine the share of the market that will switch to legal supply, we replicate the $\mathrm{PBO}$ results to translate the reported point estimates to a continuous function. ${ }^{22}$ Due to the availability of online ordering for legal marijuana, we assume that the legal market will be competitive with the illicit market in convenience to consumers. ${ }^{23}$ We use the estimated relationship between legal market share and market prices to model different legal market price scenarios and calculate their associated tax losses. Tax rates are applied consistent with the coordinated taxation

22 Legal market share $=-36.87 \ln$ (price premium $)+95.754, \mathrm{R}$-squared $=0.9895$. The above equation is estimated from the point estimates of demand elasticity between illegal and legal markets due to price differentials reported in PBO (2016), Figure 3.

23 Online ordering is available for both legal medicinal marijuana and illicit marijuana. Admittedly, assuming that the legal market will be as convenient as the illegal is a strong assumption. There is uncertainty about consumer preferences for convenience and familiarity compared to a legal supply guaranteed to be free from harmful contaminants. We assume that consumers will be indifferent between legal and illegal retail. 


\section{Figure 2: Legal Marijuana Market}

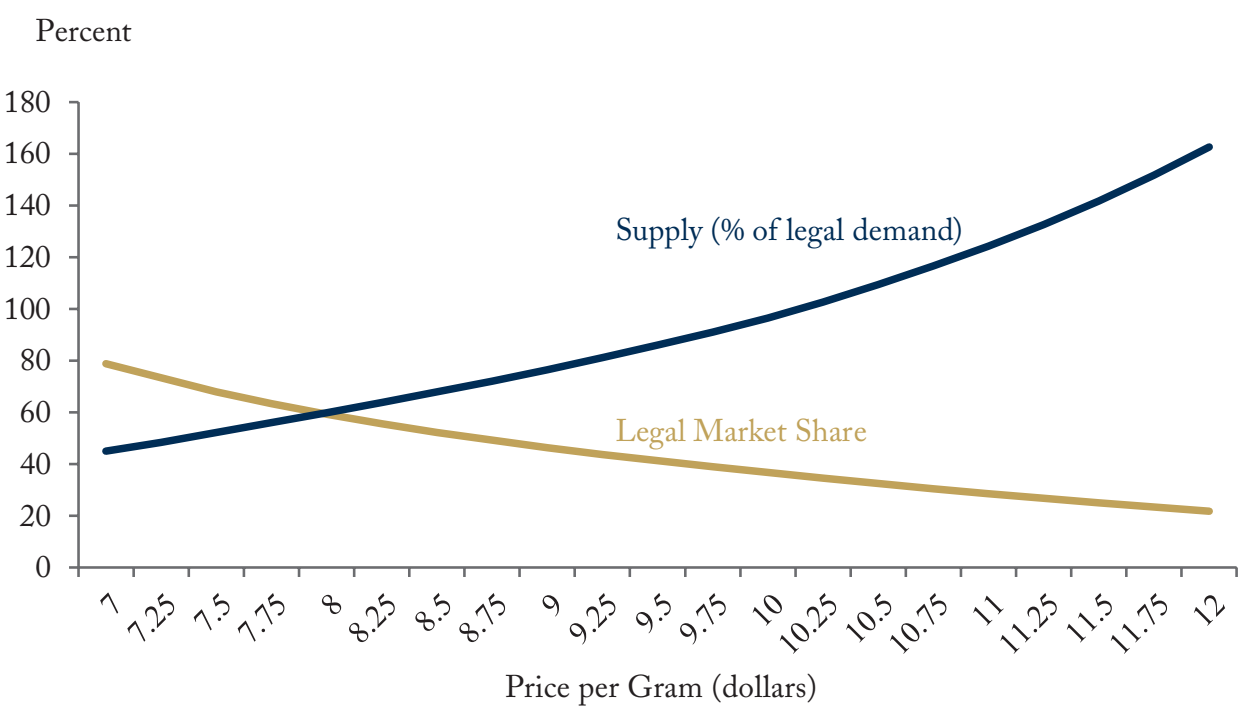

Source: PBO 2016, authors' calculations.

framework for cannabis and current provincial and federal sales taxes (GST/HST/PST/QST). ${ }^{24}$

Historically, the price per gram for legal medicinal marijuana has averaged about $\$ 8.37$ to $\$ 9.52$ (Martin 2018). There will likely be some variation in the final retail price for recreational marijuana as different provinces have different tax rates, procurement agreements and retail distribution chains. Average prices for the illicit market range from $\$ 5.86$ to $\$ 9.51$ per gram, depending on province (Statistics Canada 2018a).

To investigate the potential effects of supply shortages in the retail market context, we estimate legal market share and tax losses associated with prices in the legal market of $\$ 8$ to $\$ 10$ per gram (before taxes). At $\$ 8$, legal supplies will meet about 60 percent of demand, as the price is low enough to switch users to legal consumption. At $\$ 10$, however, legal demand makes up only about 37 percent of total demand, and legal supply will be adequate to serve about 96 percent of this demand (Figure 2).

The resulting tax losses related to both the black market and supply shortages similarly shift with price. Using the midpoint demand estimate of 592 tonnes and a before-tax price of $\$ 9$ per gram, we calculate tax losses associated with both aspects of the market. Results show that the black market remains the larger concern, with its activity associated with nearly $\$ 700$ million annually in lost tax revenue (Table 5). Supply shortages,

24 At the time of writing in September 2018, Manitoba had not signed on to the coordinated taxation framework. We assume that taxes in Manitoba will be consistent with the coordinated framework. 


\section{Table 5: Tax Losses at Midpoint Demand Estimate and a Before-Tax Legal Price of $\$ 9 / \mathrm{g}$}

\begin{tabular}{|l|c|c|c|c|}
\hline \multirow{2}{*}{} & \multicolumn{2}{|c|}{ Black Market } & \multicolumn{2}{c|}{ Supply Shortage } \\
\cline { 2 - 5 } & Excise Tax Loss & Sales Tax Loss & Excise Tax Loss & Sales Tax Loss \\
\cline { 2 - 5 } & \multicolumn{2}{|c|}{ (\$millions) } \\
\hline Canada (total) & 327.4 & 367.2 & 52.0 & 53.3 \\
\hline British Columbia & 35.1 & 27.4 & 2.7 & 2.3 \\
\hline Alberta & 22.6 & & 9.9 & 0.6 \\
\hline Saskatchewan & 7.8 & 5.4 & 0.9 & 0.2 \\
\hline Manitoba & 9.8 & 8.3 & 11.8 & 11.4 \\
\hline Ontario & 97.7 & 90.7 & 10.3 & 12.4 \\
\hline Quebec & 55.9 & 68.4 & 1.2 & 1.4 \\
\hline New Brunswick & 4.8 & 6.2 & 0.9 & 1.1 \\
\hline Nova Scotia & 6.8 & 7.9 & 0.1 & 0.1 \\
\hline Prince Edward Island & 1.1 & 1.2 & 0.3 & 0.4 \\
\hline Newfoundland and Labrador & 3.9 & 4.3 & & 23.5 \\
\hline Territories & 0.0 & & & \\
\hline Federal Government & 81.8 & & & \\
\hline Source: Authors' calculations. & & & & \\
\hline
\end{tabular}

however, will still likely cause significant tax losses totaling about $\$ 100$ million in the first full year of legalization. ${ }^{25}$

\section{POLICY IMPLICATIONS AND CONCLUSIONS}

Many of the critical questions regarding the actual implementation of marijuana legalization have been answered. However, there has been a lack of policy discussion on whether supply from existing authorized producers will be sufficient to meet expected demand. Clearly, this is important as a thriving black market can exist when the prices of legal and illegal products are comparable and supply is insufficient to meet demand. Our results

25 Note that this estimate of tax losses attributable to supply shortages in legal marijuana incorporates consideration for the black market and is significantly lower than those in the previous section which considered total recreational marijuana demand. 
show that both pricing and supply shortages will contribute to maintaining the black market, resulting in lost tax revenues and a continued need to spend significant resources on law enforcement activities related to the market. Our projections indicate the size of the black market, including legal supply shortages, will be about 380 tonnes, or at least $\$ 2.5$ billion during the first year of legalization. Our results suggest that federal and provincial revenues from excise and sales taxes on marijuana will only be about $\$ 300-\$ 600$ million in the first year of legalization. The revenues forgone due to continuing black market activity and potential supply shortages, however, could be much higher about $\$ 800$ million.

This loss can be attributed to a shifting mix of black market activity and legal market supply shortages, depending on the legal price and availability of supply. There is significant uncertainty around a number of variables that would affect actual tax losses, including recreational demand post-legalization and prices in the legal and illegal market. Using midpoint estimates for demand, our supply projections indicate that at $\$ 9$ per gram, 87 percent of the resulting tax loss would be attributed to the black market and the remaining 13 percent to supply shortage in the legal market. By extension, if the federal government were to change policies to prevent these supply shortages, it could result in increased tax revenues of about $\$ 100$ million, with $\$ 40$ million of this going into Ottawa's coffers.

There are various options that the federal government could employ to reduce this potential loss. Health Canada could further streamline the application and approval process for production and sales licences, or dedicate more resources to the processing of existing applications, which would increase legal supply faster. Another option to avoid a supply shortage would be to further delay the effective legalization of marijuana until production and inventory levels are more likely to meet legal demand, which the government has already done by delaying the effective date of legalization from July 1 to October 17. However, we do not recommend further delay, mainly because it ignores the existence of the prolific black market. Even if legal supply falls short of market demand, any consumers that switch to the legal market will be guaranteed a product safe from harmful contaminants, the consumption and corporate income will be taxed and the revenues won't fund other criminal activities.

In addition, the federal government and Health Canada should develop regulations for edible and concentrated marijuana products. These products are already available on the black market, providing a significant black market competitive advantage since they will not be part of the legal regime, at least at first. Edible products are a popular form of consumption and consumers may choose to purchase pre-made edibles from the black market instead of using legal cannabis oil to make their own. Survey results from the first quarter of 2018 indicate that 28 percent of cannabis users consume edibles, 11 percent consume hashish, 11 percent use oil cartridges or vape pens and 8 percent use solid concentrates (Statistics Canada 2018b). All these products are currently available for purchase on the black market, but will not be available at legal retail locations. The black market in Canada has been diversifying in product offerings and quality ranges. If the legal market is to be competitive, the federal government should not allow continued retail prohibition of cannabis-derived products. ${ }^{26}$

26 The illicit market can offer a wider variety of products, but may have more difficulty in establishing a brand as a signal of consistency or quality, as any brand recognition is inherently associated with openly advertising illegal activity. For their part, legal producers must comply with strict labelling and branding requirements that restrict legal producers but not illegal. It is unclear which market segment will have the better ability to establish brand power with consumers. 
Provincial governments also have a role to play in ensuring the competitiveness of the legal market. They should increase law enforcement activities related to the black market at the outset of legalization. Doing so makes participating in the black market less attractive because the risk of getting caught is higher. Those that choose to continue doing business in the illegal market will demand higher prices for marijuana than they otherwise would to compensate for the increased risk of getting caught.

In addition, the provinces regulate retail distribution, and customer experience and convenience will matter when battling it out with the black market. Retail outlets and delivery services will have to be conveniently located or easy to access and there need to be enough retail channels to meet market demand. Quebec, PEI, New Brunswick and Nova Scotia have opted for a government monopoly on retail and distribution. Nova Scotia is the only province to decide to sell marijuana out of existing liquor outlets, leveraging an already existing retail network. Other provinces that have opted for government monopoly will not have enough retail outlets to compete with the black market. Whether these provinces will be able to offer recreational consumers convenient access to legal marijuana will depend on their online ordering systems.

For its part, Ontario has opted for private retail but due to the new government's shift from the previously planned Crown corporation monopoly, will not have physical retail locations prior to April 1,2019 . While private retail will allow for greater retail coverage quickly and is ultimately a beneficial change, the delay in developing the licensing regime leaves five months when Ontario will be completely dependent on its online retail system to supply recreational consumers and compete with the black market. If retail distribution systems are not competitive with illicit suppliers, then the potential supply shortage in legal marijuana will be overshadowed by continuing black market activity.

A continuing black market and shortages of legal marijuana supply have societal impacts that extend far beyond tax revenues. For the general public, the continuation of the black market has negative health implications for recreational consumers and its revenues can fund criminal activities. Black market marijuana is not subject to regulations that ensure a product free from contaminants such as heavy metals, molds and harmful pesticides. A shortage in supply could temporarily increase prices in the legal market, making the black market relatively more attractive. For recreational consumers, this becomes a personal choice about whether they believe the consumption of black market marijuana is worth the associated health risks or whether legally regulated supply is worth the extra cost. Some consumers may simply choose not to consume marijuana unless the price of legally supplied product becomes acceptable to them (obviously, for some people, there is no price at which they will choose to consume recreational marijuana).

Shortage in a legal and regulated supply of marijuana could also adversely affect medicinal consumers. For them, marijuana consumption may not be a choice and a supply shortage could put some people in the position of choosing black market marijuana or spending significantly more for a guaranteed product. Unfortunately, the government has not made a clear distinction between cannabis used for medical purposes and recreational cannabis in the post-legalization era. As a result, in the event of a supply disruption, the market will not be able to prioritize patients who need cannabis for medical purposes and those who use it for recreational purposes.

Meanwhile, the 2018 Federal Budget provided an exemption from excise duties for "low-THC products, including low-THC cannabidiol oils, which are sometimes used by children facing certain medical conditions, and prescription pharmaceutical products that are derived from cannabis (Government of Canada 2018).”This tax exemption does give some relative price subsidization for medicinal consumers. Given that our estimates show that a supply shortage is likely, however, it is 
unclear that this tax exemption will be sufficient to ensure a reliable supply for medicinal consumers.

This is a concern that governments should address immediately. Licensed producers are likely to prioritize medicinal customers that order directly from their websites but may have reason to increase prices in medicinal and recreational markets if supply shortages manifest.

Health Canada has been licensing more producers in preparation for legalization. However, the time to germinate, grow, harvest, test, process, pack and ship a product to market means that, at least in the short term, there is a real likelihood of supply shortages in the legal market. Under UN agreements pertaining to limiting the trade in illegal drugs, countries may allow exceptions for medicinal and scientific purposes. Health Canada recently published market data on imports and exports of medical marijuana. Allowing international trade of medicinal marijuana is a prudent action by the federal government: it will allow licensed producers to import medicinal marijuana from jurisdictions with similar standards, if a shortage arises. In addition, it gives an additional reason to continue licensing producers: in the event of future excess supply, medical marijuana could become a profitable export since producers in Canada have the unique advantage of economies of scale supported by legal recreational consumption.
However, there is significant uncertainty about the scope of international marijuana trade due its illegal status and the considerable obstacles impeding product movement across international borders.

With the legalization of recreational marijuana forthcoming, governments across Canada have mobilized to tackle the myriad policy challenges. Much progress has been made on the reforming of driving and criminal rules, the regulation of retail distribution and agreements on taxation. However, all levels of government still have significant challenges ahead. Provinces should ensure regulations facilitate a competitive and convenient legal retail market. The federal government should focus on ensuring that it does not impede production more than is necessary to protect public health so there will be enough legal marijuana to supply these retail outlets. While our results predict initial shortages in legal supply, the market should be able to adjust as time goes on. It is quite possible that a supply shortage will not manifest in the legal retail market, if a significant number of consumers continue to access marijuana via black market sources. This is not a far-fetched possibility given the ease in ordering marijuana products through apps like weedmaps and the absence of brick and mortar retail locations in Ontario during the first six months of legalization. 


\section{APPENDIX}

\section{ESTIMATING SUPPLY: METHODS AND REGRESSION RESULTS}

To estimate the marijuana supply that will be available to the recreational market, we first analyzed current marijuana market data to establish a relationship among the volume of inventories in dried marijuana equivalent, the number of producers and the quantity that each produces. An increase in authorized producers should be associated with more supply and inventory (Figure 1). The number of licensed producers is lagged by nine months (three quarters) in order to take into account the gestation period between obtaining approval and actually being able to sell dried flowers.

To account for efficiency gains as producer capacities grow, the regression includes the amount produced per producer. To account for the medicinal market, the amount of medical marijuana sold per producer is also included. The resulting estimate shows that each additional licensed producer contributes 1,150 kilograms of inventory nine months after beginning production (Table A-1), which is statistically significant at the one percent level.

We also estimated alternative models to evaluate different market data variables and production lags. Marijuana is an agricultural product that can take about nine months to grow from seed to a processed product ready for consumption. ${ }^{27}$ Producers must also apply for a sales licence and have their product inspected by Health Canada before it can be sold. Some producers may be able to transfer partially mature plants from other production facilities, significantly increasing the speed of production. These factors together make it unclear exactly how long it will take the average producer to be able to sell marijuana after first receiving their production licence.

Table A-2 details some alternative model specifications. Ultimately, the choice of production lag matters only if it affects the supply projections: three-, six- or nine-month production lags between licence and first sale do not significantly affect tax-loss estimates.

\section{EQUIVALENCY FACTOR:}

Equivalency between different forms and methods of marijuana consumption is important for medical patients, recreational consumers and policy. Canadian marijuana producers are required to list equivalency factors between cannabis oils and grams of smokable product. Physicians write prescriptions in grams of marijuana per day. Equivalency between different products and its meaning must be clearly communicated to patients so that they understand how much they are authorized to order and how much to consume. ${ }^{28}$ In Colorado, the regulation of edible products (House Bill 14-1361) stipulates limits upon marijuana flower portions, "or their equivalent (Orens et al. 2015)."

27 Other market variables considered are overall production and sales volumes. For detailed regression results for those alternative specifications, please contact rwyonch@cdhowe.org.

28 Health Canada (2016b) remarks that: "There are no precise doses or established uniform dosing schedules for products such as fresh marijuana, smoked/vapourized marijuana, or cannabis oil...Other than for products that have received a notice of compliance from Health Canada and a DIN, the dose of cannabis required to achieve therapeutic effects and avoid adverse effects is difficult to estimate and is affected by many variables." 
Table A-1: Regression Results Used for Projections

\begin{tabular}{|l|c|c|c|c|}
\hline & Estimate & Robust Std. Error & t-value & $\operatorname{Pr}(>|\mathbf{t}|)$ \\
\hline (Intercept) & -24524.8 & 3518.154 & -6.9709 & $2.36 \mathrm{E}-05$ \\
\hline Number of Producers & 1150.635 & 185.875 & 6.1904 & $6.81 \mathrm{E}-05$ \\
\hline Produced per Producer & 91.17 & 10.595 & 8.605 & $3.25 \mathrm{E}-06$ \\
\hline Sold per Producer & -55.706 & 12.143 & -4.5876 & $7.81 \mathrm{E}-04$ \\
\hline
\end{tabular}

Quarterly market data covering the period April 2014 to March 2018 are sourced from Health Canada medical marijuana market data (n=15).

Source: Data for number of producers are sourced from Health Canada's public listing of ACMPR-licensed producers.

\section{Table A-2: Regression Results for Alternate Model Specifications}

\begin{tabular}{|c|c|c|c|c|c|c|c|c|c|}
\hline \multirow[b]{2}{*}{ Intercept } & \multicolumn{3}{|c|}{ 3-month lag } & \multicolumn{3}{|c|}{ 6-month lag } & \multicolumn{3}{|c|}{ 9-month lag } \\
\hline & $\begin{array}{r}-16989.5 \\
* * * *\end{array}$ & $\begin{array}{r}-17851.5 \\
* * * *\end{array}$ & $\begin{array}{r}-17922.2 \\
* * * * *\end{array}$ & $\begin{array}{r}-21822.6 \\
* *\end{array}$ & -25119.1 & -24725.3 & $\begin{array}{r}-27870.6 \\
*\end{array}$ & $-20891.8^{* * * *}$ & $\begin{array}{r}-24524.8 \\
* * * *\end{array}$ \\
\hline Number of Producers & $\begin{array}{r}1048.394 \\
* * * *\end{array}$ & $\begin{array}{r}813.31 \\
* * * *\end{array}$ & $\begin{array}{r}833.002 \\
* * * *\end{array}$ & $\begin{array}{r}1385.0 \\
* * * *\end{array}$ & 1202.735 & $\begin{array}{r}1172.798 \\
* * * *\end{array}$ & $\begin{array}{r}1755.2 \\
* * * *\end{array}$ & 917.8216 & 1150.635 \\
\hline $\begin{array}{l}\text { Produced Per } \\
\text { Producer }\end{array}$ & & $\begin{array}{r}43.40 \\
* * *\end{array}$ & 28.044 & & $\begin{array}{r}32.346 \\
* * *\end{array}$ & 42.61 & & 56.31 & $\begin{array}{r}91.17 \\
* * * *\end{array}$ \\
\hline Sold per Producer & & & 15.086 & & & -9.8335 & & & $\begin{array}{r}-55.706 \\
* * *\end{array}$ \\
\hline $\mathrm{R}$-squared & 0.936 & 0.9791 & .9778 & 0.8933 & 0.971 & 0.95 & 0.932 & 0.9454 & 0.962 \\
\hline
\end{tabular}

Note: Statistical significance of coefficients, calculated with robust standard errors, are shown below each estimate. $\left(0={ }^{(* * * *)}, 0.001=* * *\right.$, $0.01={ }^{* *}, 0.05=$ '?').

Source: Data for number of producers are sourced from Health Canada's public listing of ACMPR licensed producers (See https://www. canada.ca/en/health-canada/services/drugs-medication/cannabis/licensed-producers/authorized-licensed-producers-medical-purposes. html\#wb-cont.). Quarterly market data covering the period April 2014 to March 2018 are sourced from Health Canada medical marijuana market data (n=16, n=15 for 9-month production lag regressions) (See https://www.canada.ca/en/health-canada/services/drugs-medication/ cannabis/licensed-producers/market-data.html.).

Physical production, pharmacological/psychoactive effects and market prices are common factors that can be used to calculate an equivalency among marijuana products. Physical equivalency is calculated based on the weight of dried plant used as an input in the derivative product. Pharmacological equivalency is calculated based on the content by weight of psychoactive content (THC/CBD). In addition, the method of consumption matters: marijuana has different effects on the body, depending on whether it is inhaled or ingested. Market price equivalency among different types of marijuana products can be interpreted as a signal of consumer preference equivalency and can inform whether consumers consider quantity of psychoactive content or its effects more strongly when purchasing marijuana products. 


\section{Demand: Edibles in Colorado}

The 2015 annual update of the Marijuana Enforcement Division of the Colorado Department of Revenue reports that 109,578 pounds of medical and 38,660 pounds of recreational flowers were sold in legalization's first year. In addition, 4.8 million units of edible products were sold (Brohl, Kammerzell and Koski 2015). There is no limit on the amount of THC that medical edibles may contain, while recreational products are limited to 100 milligrams of THC per edible. Most edible products sold in Colorado contain more than one 10-milligram serving and, given the range of products available, we assume a standard concentration of 100 milligrams per edible.

In addition, the consumption method matters: marijuana has different effects on the body depending on whether it is inhaled or ingested. Dried marijuana contains an inactive form of the psychoactive compound THC (THCa). When dried marijuana is heated, the THCa decarboxylates (loses carbon and oxygen atoms), becomes bioactive and loses about 12.3 percent of its weight. Edible products contain active THC due to the production process. In addition, research suggests that when marijuana is ingested and processed by the liver, it creates THC byproducts that extend the psychoactive effects. Calculations based upon different uptake routes and speeds for psychoactive compounds estimate that one milligram of THC in edible form is equivalent to 5.71 milligrams in smokable form (Orens et al. 2015). ${ }^{29}$

To express edible product sales that occurred in Colorado during 2015 in terms of dried flower equivalent, we use the pharmacokinetic dosage equivalency:

4815650 edibles $\times \frac{10 \text { servings }}{\text { edible }} \times \frac{10 m g_{T H C}}{1 \text { servings }} \times \frac{1 g_{\text {dried flower }}}{171 m g_{T H C}} \times \frac{5.71 g_{\text {inhaled }}}{1 g_{\text {ingested }}}$

$=16,080328 \mathrm{~g}$

\section{$=16.1$ tonnes}

\section{Demand: Extracts in Washington}

Washington state allows for the sale of cannabis oils and extracts that will not be available in the legal market in Canada at the outset of legalization. These more concentrated products are converted to their equivalent in dried marijuana by relative average THC content: ${ }^{30}$

29 Pharmacokinetic equivalency is further validated by the authors' finding that Colorado's market prices reflect, almost identically, the dosing equivalencies found in the pharmacological review.

30 This equivalency estimate should be taken with more caution than those for Colorado or Canada. The average THC content for Washington estimates is sourced from estimates calculated for Colorado (Orens et al. 2015). 


\section{Table A-3: Marijuana Production in Washington State (tonnes of dried marijuana equivalent)}

\begin{tabular}{|l|c|c|c|}
\hline & $\begin{array}{c}\text { Dried } \\
\text { Marijuana }\end{array}$ & Extracts & $\begin{array}{c}\text { Total Marijuana } \\
\text { Production }\end{array}$ \\
\hline $\mathbf{2 0 1 5}$ & 35.37 & 18.23 & 53.60 \\
\hline $\mathbf{2 0 1 6}$ & 86.37 & 40.17 & 126.54 \\
\hline $\mathbf{2 0 1 7}$ & 113.28 & 63.04 & 176.33 \\
\hline
\end{tabular}

Note: Data for 2017 were available for only the first four months of the year. These values were summed and multiplied by three to estimate 2017 total demand.

Source: Monthly production data are sourced from the Washington State Liquor and Cannabis Board Marijuana Dashboard and covers the period January 2015 to April 2017.

$$
X g_{\text {oil }} \times \frac{1 g_{\text {dried flower }}}{0.28 g_{\text {oil }}}=X g_{\text {dried flower }}
$$

Since both concentrated extracts and dried marijuana are inhaled, the pharmacokinetic effects are similar, and the amount of psychoactive substance is the appropriate comparator (Orens et al. 2015). The resulting estimates of production in Washington are shown in Table A-3.

\section{Supply: Cannabis Oil in Canada}

Inventories of marijuana are held in dried marijuana and cannabis oil and reported in kilograms. Cannabis oils are intended for ingestion and contain different amounts of THC/CBD per gram than dried marijuana. The amount of psychoactive compound and its effects must be considered to convert cannabis oil inventories to their dried marijuana equivalent.

In Canada, registered producers are required to list an equivalency for their products. As of Dec. 14, 2017, there were 76 ACMPR producers of cannabis oils (Martin 2017). Using potency data from ACMPR producer websites, we calculate a weight equivalency between cannabis oils and dried flowers in Canada. Cannabis oil potency is listed in milligrams of psychoactive compound per millilitre. This is converted to weight via the commonly listed density for carrier oils used in the production of cannabis oil $(1 \mathrm{ml}=0.92 \mathrm{~g})$. Dried flower potency is listed in milligrams of psychoactive compound per gram. The relative potency yields a weight equivalency factor.

To evaluate the estimated equivalency factor, we compare this result to listed average equivalency factors from licensed producer websites. Each licensed producer is required to list millilitres of cannabis oil equivalent to one gram of dried marijuana. There are some limitations to using the producer-posted equivalency factor: some websites do not list an equivalency factor on the public portion and listed equivalencies represent the average or target potency and do not account for potency differences between offerings or production batches. Cannabis oils are intended for consumption and multiple licensed 


\section{Table A-4: Equivalency between Dried Marijuana and Cannabis Oil Inventories}

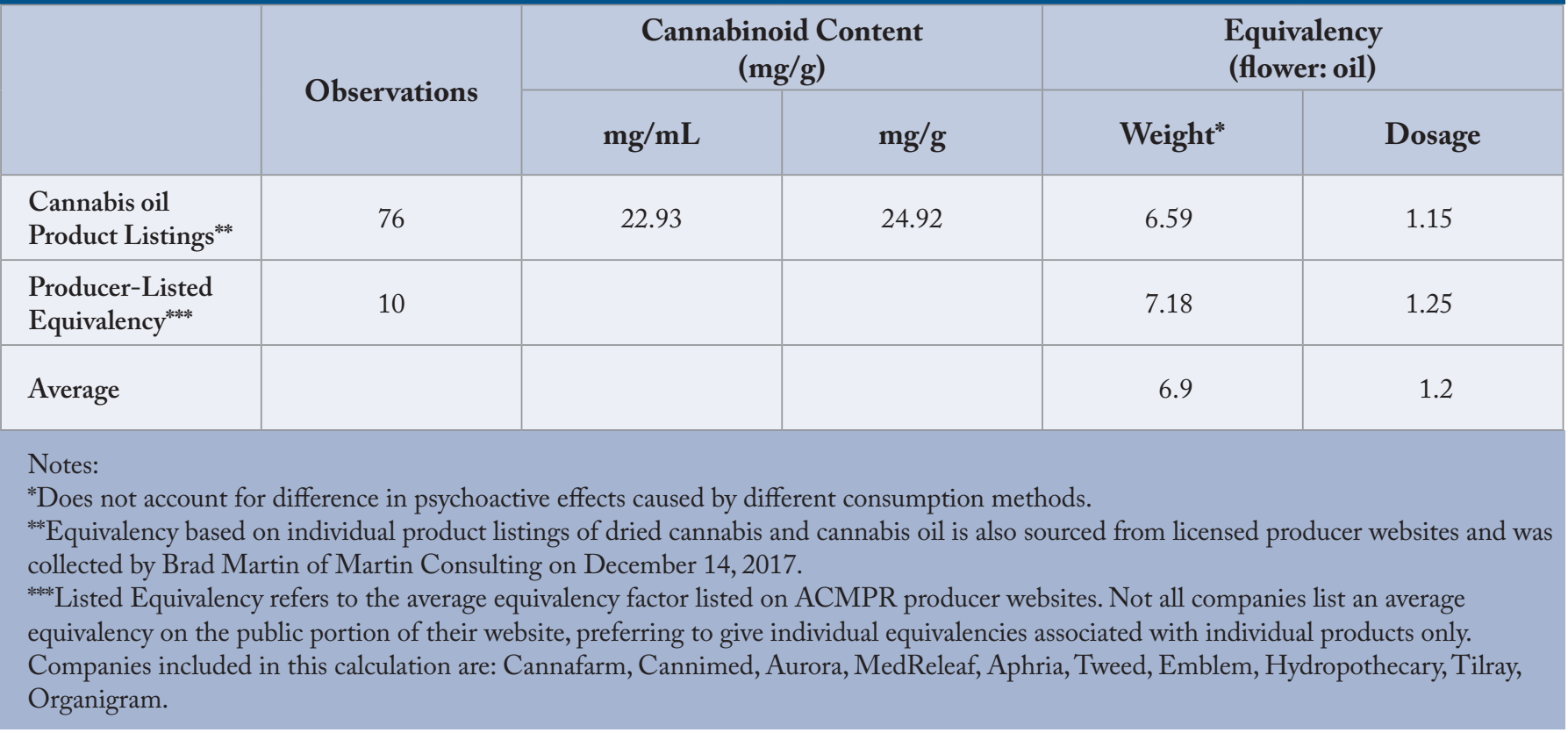

\section{Table A-5: Price Ratios, Equivalency Factors and Consumer Preferences}

\begin{tabular}{|l|c|c|}
\hline & Cannabis Oil & $\begin{array}{c}\text { Price Ratio } \\
\text { (dried marijuana: } \\
\text { cannabis oil) }\end{array}$ \\
\hline Purchase Price $(\$ / g)$ & 2.90 & 9.10 \\
\hline Cannabinoid content $(\$ / \mathrm{mg})$ & 0.12 & 0.06 \\
\hline $\begin{array}{l}\text { Pharmacokenetic }-(\$ / \mathrm{mg} \text { cannabinoid content, adjusted for } \\
\text { consumption method) }\end{array}$ & 0.02 & 0.06 \\
\hline Source: Authors' calculation. & & 0.49 \\
\hline
\end{tabular}

producers warn not to smoke or vaporize them. This means that weight-equivalency does not account for the differing pharmacokinetic effects of ingesting and inhaling cannabis. Similar to calculations for market demand, we incorporate the pharmacokinetic effects into our equivalency factor.

$$
\text { equivalency factor }(\text { flower }: \text { oil })=\frac{\text { potency }(\text { oil }) \times \text { density }(\text { oil })}{\text { potency }(\text { dried flower })} \times \frac{1 g_{\text {ingested }}}{5.71 g_{\text {inhaled }}}
$$


The resulting estimates show that one gram of dried cannabis is equivalent to about 6.9 grams of oil by weight and about 1.2 grams by psychoactive effect (Table A-4). The equivalency estimated from individual product listings is very similar to those posted by producers.

To determine which equivalency is more relevant to consumers - amount of psychoactive substance or its effects - we examine the price equivalency between dried cannabis and cannabis oil by comparing the market price equivalency by volume of product to that for quantity of psychoactive compound or its effects. The purchase price equivalency is similar to that for the price equivalency of psychoactive effect between dried cannabis and oil (Table A-5). This signals that consumers consider the psychoactive effect more strongly than the amount of psychoactive compound in each cannabis product. In addition, results from Colorado show that price ratios match quite closely with the pharmacokinetic equivalency ratios (Orens et al. 2015). This means that even though consumers may be unaware of the differences in psychoactive effects, prices act as an effective signal. This validates the use of the pharmacokinetic equivalency as the conversion factor for cannabis oil to dried marijuana equivalent. Given the similarity of the equivalency factor, estimates calculated from individual product listings and producer websites, we use the average value of 1.2 grams dried marijuana = one gram cannabis oil to convert licensed producer inventories. 


\section{REFERENCES}

Allard, Neil, Tanya Beemish, David Hebert, and Shawn Davey v. Her Majesty The Queen in Right of Canada. 2016 FC 236. Available at: http://cas-cdcwww02.cas-satj.gc.ca/rss/T-2030-13\%20reasons $\% 20$ 24-02-2016\%20(ENG).pdf.

Brohl, Barbara, Ron Kammerzell, and W. Lewis Koski. 2015. Enforcement Division - Marijuana: Annual Update. Colorado Department of Revenue: Colorado. February 27. Available at: https://www. colorado.gov/pacific/sites/default/files/2014\%20 MED\%20Annual\%20Report_1_1.pdf.

Cyrenne, Philippe, and Marian Shanahan. 2017.

"Toward a Regulatory Framework for the Legalization of Cannabis: How Do We Get to There from Here?" Canadian Public Policy. 44(1):5476. February. Available at: https://www.utpjournals. press/doi/abs/10.3138/cpp.2017-026.

Department of Finance (a). 2017. "Proposed Excise Duty Framework for Cannabis Products." Government of Canada: Ottawa. November 10. Available at: https://www.fin.gc.ca/n17/data/17114_1-eng.asp.

(b). 2017. "Backgrounder:

Federal-Provincial-Territorial Agreement on Cannabis Taxation." Government of Canada: Ottawa. December 11. Available at: https://www.fin. gc.ca/n17/data/17-122_1-eng.asp.

Easton, Stephen. 2004. "Marijuana Growth in British Columbia.” Public Policy Sources. Vol 74. The Fraser Institute: Vancouver. Available at: https://www.fraserinstitute.org/sites/default/files/ MarijuanaGrowthinBC.pdf.

Galenianos, Manolis, Rosalie Pacula, and Nicola Persico. 2012. "A search-theoretic model of the retail market for illicit drugs." Review of Economic Studies 79:1239-69.

Government of Canada. 2018. "Equality + Growth: A Strong Middle Class.” Available at: https://www. budget.gc.ca/2018/docs/plan/budget-2018-en.pdf.
Hansen, Benjamin, Keaton Miller, and Caroline Weber. 2017. "The Taxation of Recreational marijuana: evidence from Washington state.” NBER working paper 23632. National Bureau of Economic Research. Massachusetts. July.

Health Canada. 2018. "Drug and Health Products: Licensed Producers: Market Data.” Retrieved 2018-04-18 at https://www.canada.ca/en/healthcanada/services/drugs-health-products/medicaluse-marijuana/licensed-producers/market-data. html\#wb-cont.

to Cannabis for Medical Purposes Regulations." Ottawa: August. Available at: https://www.canada. ca/en/health-canada/services/publications/drugshealth-products/understanding-new-access-tocannabis-for-medical-purposes-regulations.html. 2016b. "Access to Cannabis for Medical Purposes Regulation - Daily Amount Fact Sheet (Dosage).” Government of Canada: Ottawa. July. Available at: https://www.canada.ca/en/healthcanada/services/drugs-medication/cannabis/ information-medical-practitioners/cannabismedical-purposes-regulations-daily-amount-factsheet-dosage.html.

Jacobi, Liana, and Michelle Sovinsky. 2016. "Marijuana on Main Street? Estimating Demand in Markets with Limited Access." American Economic Review. 106(8): 2009-45. August.

LeBlanc, Daniel, and Mike Hagar. 2017. “Canada’s marijuana legalization plan designed to reduce criminal role in market." The Globe and Mail: Toronto. April 13. Available at: https://www. theglobeandmail.com/news/politics/liberals-tablemarijuana-bill-that-includes-crackdown-onimpaired-drivers/article34696586/.

LeDain, Gerald, Heinz Lehmann, and J. Peter Stein. The Report of the Canadian Government Commission of Inquiry into the Non-Medical Use of Drugs - 1972. Conclusions and Recommendations. Information Canada. Ottawa. Available at: http://www.druglibrary.org/ schaffer/library/studies/ledain/ldc6a.htm. 
Light, Miles K. et al. 2016. "Market Size and Demand for Marijuana in Colorado." Prepared for the Colorado Department of Revenue. V16. Available at: http://www.mjpolicygroup.com/pubs/CODemand-Study-Public.pdf.

Macdonald, Ryan, and Michelle Rotermann. 2017. "Experimental estimates of Cannbis Consumption in Canada, 1960 to 2015.” Available at: https://www. statcan.gc.ca/pub/11-626-x/11-626-x2017077-eng. htm.

MacKay, Robin, and Karin Phillips. 2016.

"Regulation of Marijuana in Canada and Selected Other Countries." Government of Canada, Library of Parliament: Ottawa. September 6. Available at: https://lop.parl.ca/Content/LOP/ ResearchPublications/2016-94-e.html.

Martin, Brad. 2018. "Historical Price Per Gram of Dried Cannabis from ACMPR Licensed Producers.” February 15. Available at: http://cannstandard.ca/ historical-price-per-gram-of-dried-cannabis-fromacmpr-licensed-producers.

Office of the Parliamentary Budget Officer. 2016. "Legalized Cannabis: Fiscal Considerations." Ottawa, Canada. November 1. Available at: http://www.pbo-dpb.gc.ca/web/default/files/ Documents/Reports/2016/Legalized\%20 Cannabis/Legalized\%20Canabis\%20Fiscal\%20 Considerations_EN.pdf.

Orens, Adam, et al. 2014. "Market Size and Demand for Marijuana in Alaska." October 27. Available at: http://www.mjpolicygroup.com/pubs/AlaskaDemand-and-Taxes.pdf. 2015. "Marijuana Equivalency in Portion and Dosage: An assessment of physical and pharmacokinetic relationships in marijuana production and consumption in Colorado." Prepared for the Colorado Department of Revenue. Available at: http://www.mjpolicygroup.com/pubs/MPG_ Equivalency_Study_Public.pdf.
Ouellet, Marie, et al. 2017. "The Price of Cannabis in Canada." Research Report: 2017-R005. Research Divisions. Public Safety Canada. Available at: https://www.publicsafety.gc.ca/cnt/rsrcs/ pblctns/2017-r005/2017-r005-en.pdf.

Perkel, Colin. 2017. Pot black market isn't expected to disappear even as marijuana becomes legal. Canadian Press. December 4. Available at: https://www. cbc.ca/news/world/pot-cannabis-marijuanaillegal-1.4431419

R. v. Parker (2000), Ont. C.A. 359. Available at: http:// www.ontariocourts.ca/decisions/2000/july/parker. pdf.

Sen, Anindya, and Rosalie Wyonch. 2017. "Don't (Over) Tax that Joint My Friend.” Intelligence Memo. Toronto: C.D. Howe Institute. July 17. Available at: https://www.cdhowe.org/intelligence-memos/senand-wyonch-dont-over-tax-joint-my-friend.

Senate Special Committee on Illegal Drugs. 2002. Cannabis: Summary Report. Ottawa. September. Available at: https://sencanada.ca/content/sen/ committee/371/ille/rep/summary-e.pdf.

Statistics Canada. 2018 (a). "Cannabis Stats Hub: Economy: Household Consumption Expenditure (Quantity), 2017.” Available at: http://www.statcan. gc.ca/pub/13-610-x/cannabis-eng.htm.

\section{8 (b). "National Cannabis}

Survey, first Quarter 2018.” Available at: https:// www150.statcan.gc.ca/n1/daily-quotidien/180418/ dq180418b-eng.htm.

United Nations Office on Drugs and Crime. 2017. Market Analysis of Plant-Based Drugs: opiates, cocaine, cannabis. World Drug Report 2017. Booklet 3. Austria: Vienna. May. Available at: https://www. unodc.org/wdr2017/field/Booklet_3_Plantbased. pdf. 
NOTES: 


\section{NOTES:}


NOTES: 


\section{ReCEnt C.D. Howe Institute Publications}

October 2018 Laurin, Alexandre, and Farah Omran. Piling On-How Provincial Taxation of Insurance Premiums Costs Consumers. C.D. Howe Institute Commentary 522.

September 2018 Laurin, Alexandre. "Unhappy Returns: A Preliminary Estimate of Taxpayer Responsiveness to the 2016 Top Tax Rate Hike." C.D. Howe Institute E-Brief.

September 2018 Ezra, David Don. Making the Money Last: The Case for Offering Pure Longevity Insurance to Retiring Canadians. C.D. Howe Institute Commentary 521.

September 2018 Robson, William B.P., Jeremy Kronick, and Jacob Kim. Tooling Up: Canada Needs More Robust Capital Investment. C.D. Howe Institute Commentary 520.

September 2018 Meunier, Denis. Hidden Beneficial Ownership and Control: Canada as a Pawn in the Global Game of Money Laundering. C.D. Howe Institute Commentary 519.

August 2018 Skuterud, Mikal, and Zong Jia Chen. Comparing Outcomes: The Relative Job-Market Performance of Former International Students. C.D. Howe Institute Commentary 518.

August 2018 Milligan,Kevin, and Tammy Schirle. "Rich Man, Poor Man: The Policy Implications of Canadians Living Longer.” C.D. Howe Institute E-Brief.

August 2018 Dachis, Benjamin. "Hosing Homebuyers: Why Cities Should Not Pay For Water and Wastewater Infrastructure with Development Charges.” C.D. Howe Institute E-Brief.

August 2018 Ciuriak, Dan. “The March into Trade Wars: US Policy Aims and the Implications for Reconciliation.” C.D. Howe Institute Verbatim.

July 2018 Schwanen, Daniel. "Foreign Direct Investment in Canada - The Case for Further Openness and Transparency." C.D. Howe Institute E-Brief.

July 2018 Dachis, Benjamin. "Speed Bump Ahead: Ottawa Should Drive Slowly on Clean Fuel Standards.” C.D. Howe Institute E-Brief.

July 2018 Zelmer, Mark, and Jeremy Kronick. International Prudential Standards in a World of Growing Nationalism and Protectionism. C.D. Howe Institute Commentary 517.

juin 2018 Genest-Grégoire, Antoine, Luc Godbout, René Beaudry, et Bernard Morency. « Report des prestations des régimes de retraite : un outil de flexibilité. » Institut C.D. Howe Cyberbulletin.

\section{SUPPORT THE INSTITUTE}

For more information on supporting the C.D. Howe Institute's vital policy work, through charitable giving or membership, please go to www.cdhowe.org or call 416-865-1904. Learn more about the Institute's activities and how to make a donation at the same time. You will receive a tax receipt for your gift.

\section{A REPUTATION FOR INDEPENDENT, NONPARTISAN RESEARCH}

The C.D. Howe Institute's reputation for independent, reasoned and relevant public policy research of the highest quality is its chief asset, and underpins the credibility and effectiveness of its work. Independence and nonpartisanship are core Institute values that inform its approach to research, guide the actions of its professional staff and limit the types of financial contributions that the Institute will accept.

For our full Independence and Nonpartisanship Policy go to www.cdhowe.org. 

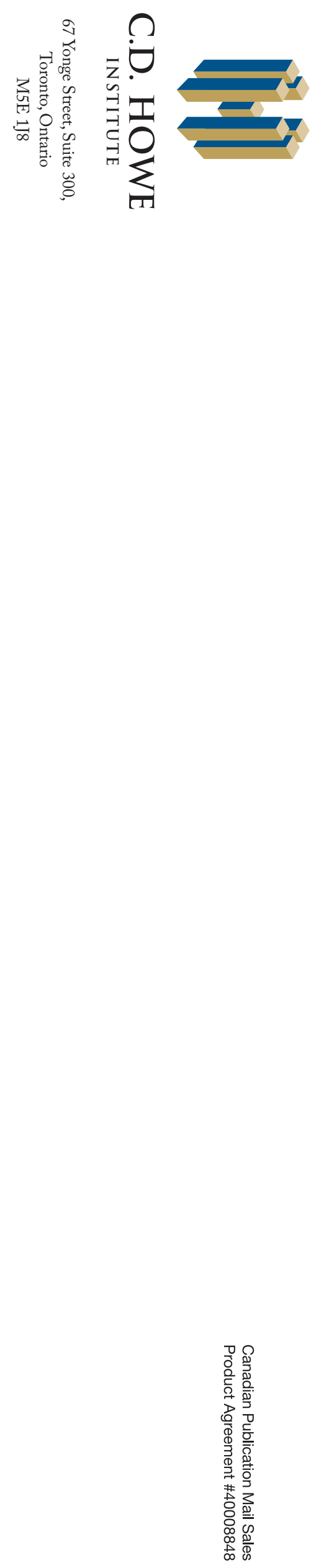